\title{
FK506 Augments Glucocorticoid-Mediated Cyclooxygenase-2 Down-Regulation in Human Rheumatoid Synovial Fibroblasts
}

\author{
Kiyoshi Migita, Hirotoshi Tanaka, Kensaku Okamoto, Noritada Yoshikawa, \\ Yasufumi Ichinose, Satoshi Urayama, Satoshi Yamasaki, Hiroaki Ida, \\ Yojiro Kawabe, Atsushi Kawakami, and Katsumi Eguchi
}

The First Department of Internal Medicine (KM, YI, SU, SY, HI, YK, AK, KE), Nagasaki University School of Medicine, Nagasaki and Second Department of Internal Medicine (HT, KO, NY), Asahikawa Medical College, Asahikawa, Japan

\begin{abstract}
SUMMARY: Prostaglandins (PG) formed by cyclooxygenase (COX) enzymes are important mediators of inflammation in rheumatoid arthritis. The contribution of the inducible COX-2 to inflammation in the rheumatoid synovium is well documented. We examined the regulation of COX-2 mRNA and protein expression in response to both glucocorticoids (GC) and FK506 using rheumatoid synovial fibroblasts. Combined treatment of FK506 and a low concentration of dexamethasone (DEX) (10 ${ }^{-9}$ M) down-regulated synovial COX-2 mRNA and protein expression. In contrast, neither FK506 nor DEX (10 $\left.{ }^{-9} \mathrm{M}\right)$ alone influenced COX-2 expression. Immunocytochemical studies showed that pretreatment with FK506 enhanced the nuclear translocation of the glucocorticoid receptor (GR) in synovial fibroblasts in the presence of low concentrations of DEX $\left(10^{-9} \mathrm{M}\right)$. Transient transfection experiments showed that treatment of cells with FK506 enhanced the expression of glucocorticoid-responsive gene reporter in the presence of DEX $\left(10^{-9} \mathrm{M}\right)$. NF- $\kappa \mathrm{B}$ is known to mediate the transcriptional activation of the COX-2 gene. Electrophoretic mobility shift assay demonstrated that DNA-binding activity of NF- $\kappa B$ was suppressed more profoundly by FK506 plus DEX (10 ${ }^{-9}$ M) treatment with those of DEX $\left(10^{-9} \mathrm{M}\right)$ alone in IL-1 $\beta$-stimulated synovial cells. Our results indicated that FK506-induced potentiation of GR-mediated repression of synovial COX-2 gene transcription is the result of increased translocation of GR to the nucleus and subsequent repression of NF- $\kappa$ B transactivation. Our results also suggest that FK506 may exert anti-inflammatory effects in the rheumatoid synovium by potentiating GR-mediated signal transduction. (Lab Invest 2000, 80:135-141).
\end{abstract}

$R$ heumatoid arthritis (RA) is an inflammatory joint disease in which perpetuation of synovitis leads to articular destruction (Zvaifler and Firestein, 1994). Rheumatoid synovial fibroblasts release various inflammatory mediators (Dayer et al, 1986). Prostaglandin (PG), one of the important mediators in rheumatoid synovitis, is synthesized by cyclooxygenases (COX) (Salmon et al, 1983; Wittenberg et al, 1993). It has been demonstrated that COX-2, an inducible COX isoform, is expressed in rheumatoid synovial fibroblasts and that treatment with $\mathrm{IL}-1 \beta$ induces the synthesis of COX-2 mRNA and protein, while glucocorticoids (GC) suppress this induction (Crofford et al, 1994).

GC has been used for decades as a clinical tool to suppress inflammatory and immune responses. GC action is known to be mediated by cellular glucocorticoid receptors (GR) (Bamberger et al, 1996). The binding of GC is followed by a conformational change in GR; the hormone-receptor complex translocates to

Received August 19, 1999.

Address reprint requests to: Dr. K. Migita, The First Department of Internal Medicine, Nagasaki University School of Medicine, Sakamoto 1-7-1, Nagasaki 852-8501, Japan. Fax: 8195849 7270; E-mail: eguchi@net.nagasaki-u.ac.jp the nucleus and binds to its acceptor site in DNA (Truss and Beato, 1993). In the cytoplasm, GR associates with several heat shock proteins (Pratt, 1993; Smith and Toft, 1993). Recent studies showed that the GR complex also contains members of the immunophilin class of proteins (Tai et al, 1992). Furthermore, Yem et al (Yem et al, 1992) reported that FK506-binding protein (FK-BP) is associated with the GR complex. This association between FK-BP and GR suggests that immunophilin and steroid receptormediated signal transduction pathways may be functionally convergent.

In the present study, we investigated the effects of two immunosuppressive drugs, FK506 and GC, on rheumatoid synovial cell function. Our results showed that FK506 combined with low concentrations of DEX results in a marked suppression of COX-2 mRNA and protein expression.

\section{Results \\ Effects of DEX and FK506 on Synovial COX-2 mRNA Expression}

As described previously, DEX, ranging in concentration from $10^{-8}$ to $10^{-7} \mathrm{M}$, inhibited the constitutive expression of COX-2 mRNA in synovial fibroblasts. 
Synovial fibroblasts were incubated with FK506 (100$1000 \mathrm{~nm}$ ) for 2 hours followed by the addition of DEX and further incubation for 6 hours. Total cellular RNA was extracted and RT-PCR was performed (Fig. 1). COX-2 mRNA was detected in synovial fibroblasts under basal conditions. $10^{-8} \mathrm{M}$ of DEX inhibited COX-2 mRNA expression, although no inhibition of expression was noted at concentrations below $10^{-9}$ M. Pre-treatment with FK506 further suppressed synovial COX-2 mRNA expression in the presence of $10^{-9} \mathrm{M}$ of DEX. FK506 pretreatment alone did not inhibit the COX-2 mRNA expression.

\section{Effects of DEX and FK506 on Synovial COX-2 Protein Expression}

Figure 2 shows an immunoblot of synovial cell lysates probed with anti-COX-2 antiserum. Before stimulation with IL-1 $\beta(5 \mathrm{U} / \mathrm{ml})$, there was no measurable level of immunoreactive protein. Because COX-2 is a shortlived protein (Evett et al, 1993), its protein expression may not be detected by immunoblot in the basal condition. After 12 hours of IL-1 $\beta$ stimulation, a clear COX-2 immunoreactive band of $72 \mathrm{kDa}$ became evident. No change was noted in IL-1 $\beta$-induced COX-2 expression in the presence or absence of $10^{-9} \mathrm{M}$ of DEX. However, synovial cells pretreated with FK506 followed by DEX contained much reduced levels of COX-2 protein compared with synovial cells treated with DEX alone without pretreatment with FK506. FK506 pretreatment alone did not affect IL-1 $\beta$ induced COX-2 expression on synovial cells.

\section{Immunofluorescence Study of Subcellular Localization of GR}

We also examined the effects of FK506 on the subcellular distribution of the GR using indirect immunofluorescent analysis of synovial fibroblasts obtained from RA patients. In the absence of either DEX or FK506, the green fluorescence was mainly localized in the cytoplasm (Fig. 3). After a 2-hour treatment with the indicated concentrations of DEX, GR fluorescence gradually shifted to the nucleus in a concentrationdependent manner, indicating that synovial fibroblasts

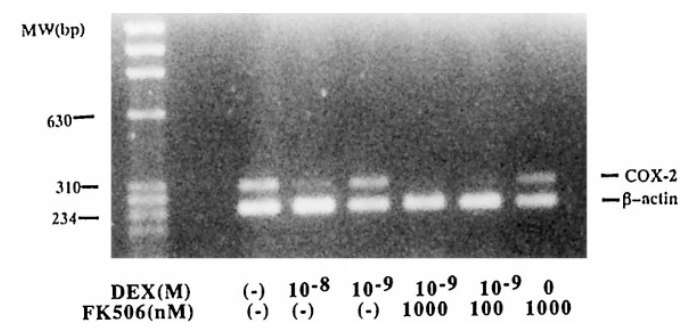

Figure 1.

Effects of dexamethasone (DEX) and FK506 on COX-2 mRNA expression. Rheumatoid synovial fibroblasts were pretreated with FK506 for 2 hours and with DEX for the last 6 hours of incubation. Total RNA was reverse transcribed after PCR amplification with primers for COX-2 and $\beta$-actin. Ethidium bromide staining of PCR products was performed after 25 cycles of amplification and separation in a $1.5 \%$ agarose gel. A representative example of three rheumatoid arthritis (RA) patients showing similar results.
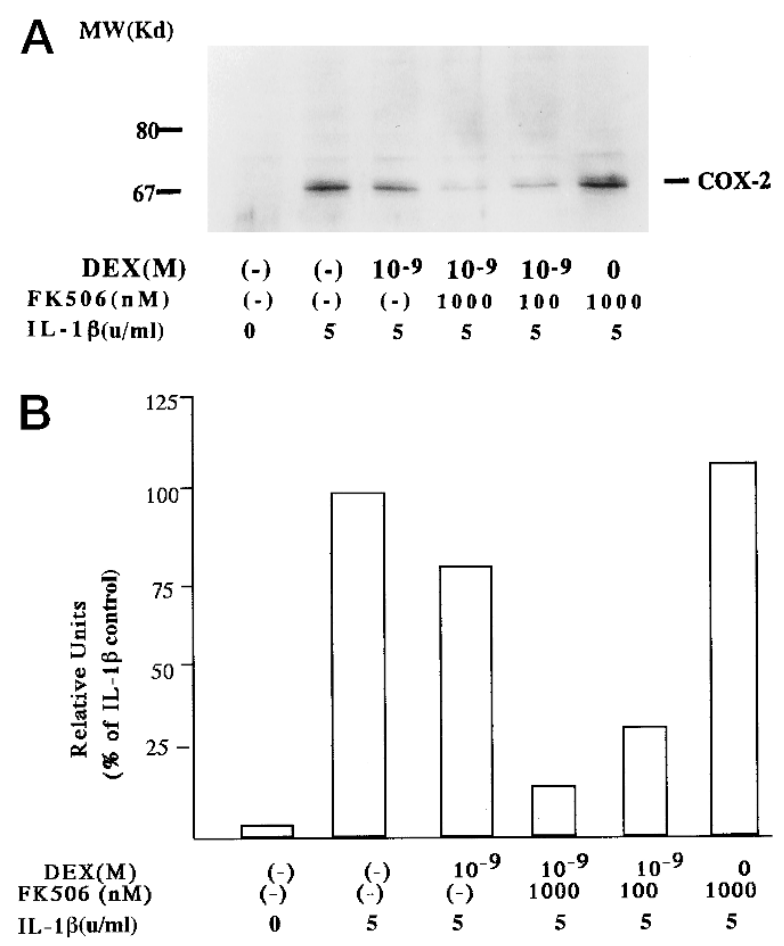

Figure 2.

$A$, Effects of DEX and FK506 on COX-2 protein expression. Rheumatoid synovial fibroblasts were pretreated with FK506 for 2 hours. The cells were stimulated with IL-1 $\beta(5 \mathrm{U} / \mathrm{ml})$ in the presence of $10^{-9} \mathrm{M}$ of DEX for 12 hours. The cells were lysed and lysates were analyzed by anti-COX-2 immunoblot. A representative example of three $\mathrm{RA}$ patients showing similar results. $B$, Results were calculated as a relative unit by densitometer. IL-1 $\beta$ control was assigned the value of $100 \%$. Data were expressed as the percentage of IL-1 $\beta$ control.

from RA patients contain functional GR. To test the effect of FK506 on the GR, cells were cultured in the presence of the indicated concentration of DEX and FK506. As shown in Figure 3, FK506 clearly increased nuclear fluorescence of the GR. This additive effect of FK506 was evident at relatively lower concentrations of DEX (eg, 1 and $10 \mathrm{~nm}$ ), and appeared to be saturated in the presence of $100 \mathrm{~nm}$ DEX.

\section{Transcriptional Control of Glucocorticoid-Inducible Promoter by FK506}

To test the effect of FK506 on the transactivational function of the GR, synovial cells were transfected with a GC-inducible luciferase reporter plasmid pGRELuc and cultured in the presence or absence of DEX and FK506, as indicated. As shown in Figure 4, treatment with DEX resulted in a concentrationdependent increase in reporter gene expression, indicating that cellular GR is transcriptionally functional. Addition of $1 \mu \mathrm{M}$ FK506 resulted in an approximately 2 -fold increase in luciferase activity at relatively lower concentrations of DEX (eg, 1 and $10 \mathrm{~nm}$, Fig. 4). However, FK506 showed no significant effect on reporter gene expression at 100 nM DEX (Fig. 4). From this result, together with those of indirect immunofluorescent analysis, we conclude that FK506 potentiates GC hormone action, most likely through promotion of its ligand-dependent nuclear translocation. 


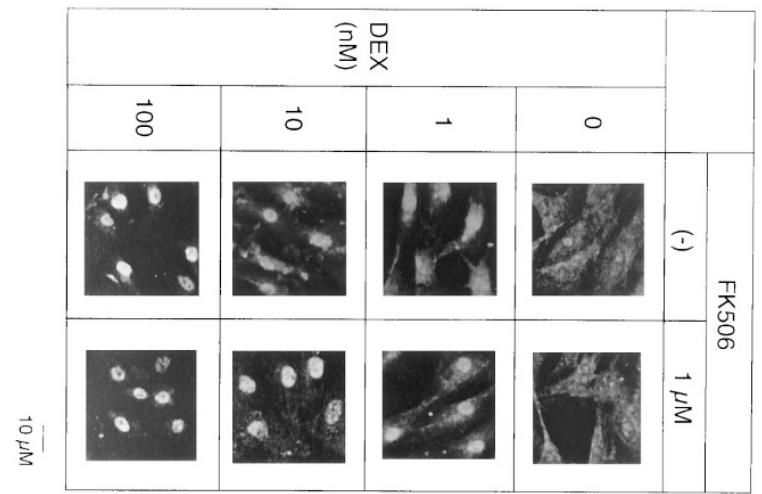

Figure 3.

Effect of DEX and FK506 on the subcellular localization of GR. Synovial fibroblasts isolated from RA patients were cultured in the presence of DEX and FK506 as indicated, and subcellular localization of the GR was analyzed using a confocal laser microscope. A representative example of three RA patients showing similar results.

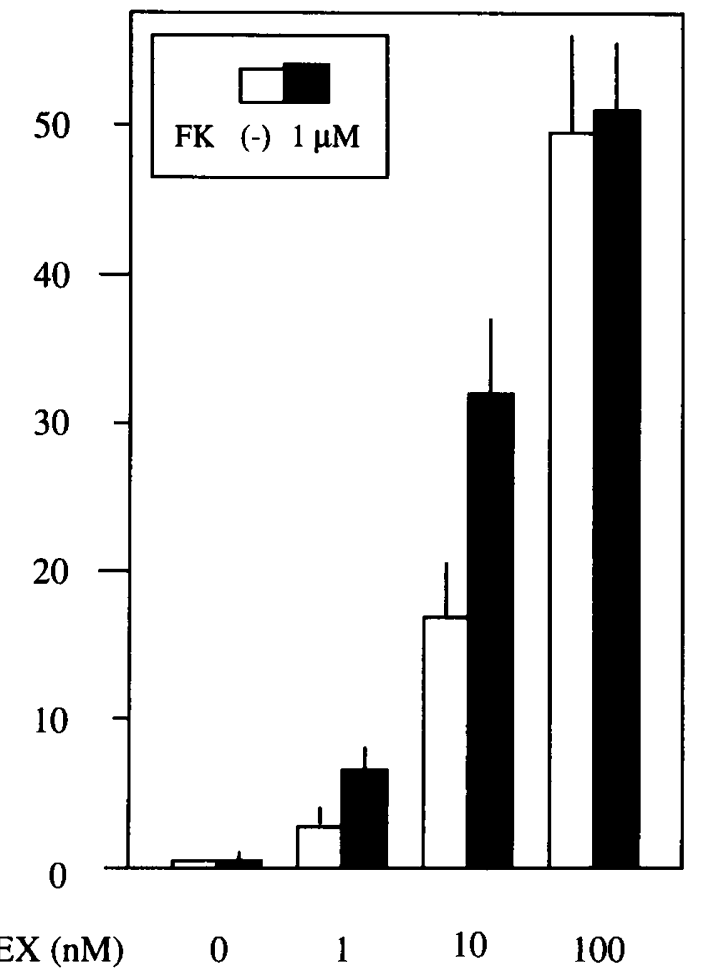

Figure 4.

Additive effects of FK506 on glucocorticoid (GC)-inducible gene expression. Synovial fibroblasts were transfected with the GC-responsive reporter plasmid pGRE-Luc and cultured in the presence of DEX and FK506, as indicated. The data represent the mean \pm SD of three independent experiments.

\section{Effects of FK506 on the DNA-Binding Activity of NF-кB}

Recent studies indicate that GR and NF- $\kappa \mathrm{B}$ physically interact and function as antagonists (Caldenhoven et al, 1995). To examine the molecular mechanism of the FK506 effect on COX-2 expression, we performed EMSA using the oligonucleotide-encompassing NF-kB element as a probe. The promoter region of COX-2 contains an NF-kB element that is known to be

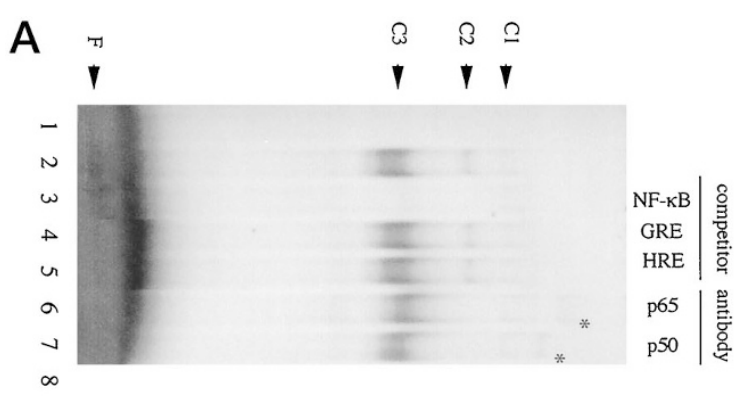

B

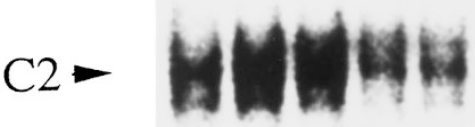

$$
\begin{array}{llllllll}
\mathrm{IL}-1 \beta(5 \mathrm{uml}) & - & + & + & + & + & + & + \\
\operatorname{Dex}(1 \mathrm{nM}) & - & - & + & - & + & + & + \\
\text { FK506 }(\mu \mathrm{M}) & - & - & - & 1 & 0.01 & 0.1 & 1
\end{array}
$$

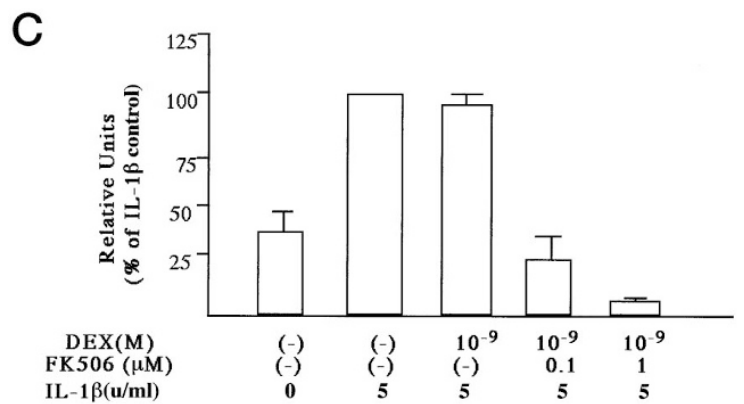

Figure 5.

A, Protein components of protein-DNA complexes formed between the nuclear extracts from RA synovial cells and a NF-kB oligonucleotide probe. Synovial cells were treated with (lane 2 to lane 7 ) or without IL-1 $\beta$ (lane 1). After incubation with a ${ }^{32} \mathrm{P}$-labeled NF- $\kappa$ B oligonucleotide probe, samples were run on $4 \%$ native PAGE and gel was dried and autoradiographed. If indicated, 20 times molar excess of competitor oligonucleotides or antibodies were included in the reaction mixtures. C1, C2, and C3, positions of protein-DNA complexes were formed between the NF-kB probe and nuclear extracts. F, position of free probe. B, Effect of IL-1 $\beta$, Dex, and FK506 on NF- $\kappa$ B DNA-binding activity. Synovial cells were treated with IL-1 $\beta$, Dex, and FK506, as indicated, and nuclear extracts were prepared and $\mathrm{C} 2$ complex formation was monitored in EMSA. C, Effect of IL-1 $\beta$, Dex, and FK506 on NF- $\kappa$ B DNA-binding activity. NF- $\kappa B$ DNA-binding activity (C2 position) was calculated as a relative unit by densitometer. IL-1 $\beta$ control was assigned the value of $100 \%$, and data were expressed as the percentage of IL-1 $\beta$ control. Data represent the mean \pm SD of two separate experiments.

a target of IL-1 $\beta$-dependent induction of COX-2 (Crofford et al, 1997) .

As shown in Figure $5 \mathrm{~A}$, IL-1 $\beta$ stimulation produced several protein-DNA complexes; C1, C2, and C3. C1 was not inhibited by excess amounts of either specific (NF-kB element) or non-specific oligonucleotide (GRE and HRE) (lanes 2 to 5), suggesting that $C 1$ is a nonspecific complex. In contrast, formation of $\mathrm{C} 2$ and C3 was inhibited only by NF-kB oligonucleotide. Antibody supershift experiments demonstrated that $\mathrm{C} 2$ contained both p65 and p50 (lanes 7 and 8). The components of $\mathrm{C} 3$ remained unknown. Because the heterodimer of p65 and p50 is a major component of 
cytokine-inducible NF-kB, we focused on $\mathrm{C} 2$ and tested the effect of treatment with DEX and FK506. As shown in Figure $5 \mathrm{~B}$, treatment with IL-1 $\beta$ significantly induced the DNA-binding activity of NF-kB p50/p65 (lanes 1 and 2). Addition of a low concentration of DEX (1 nm) alone did not influence NF-kB activity. However, a high concentration of FK506 reduced NF-kB DNAbinding activity. Moreover, concomitant addition of FK506 with DEX further decreased NF-kB DNA binding activity in a concentration-dependent manner (Fig. 5C).

\section{Discussion}

GC has been widely used as a potent immunosuppressive drug. GC binds to cytoplasmic GR, a member of the steroid hormone receptor superfamily, which translocates to the nucleus as a transcription factor (Bamberger et al, 1996). In the cytoplasm, GR associates with several chaperone particles, such as heat shock proteins (Smith and Toft, 1993). GR requires dissociation with these proteins for nuclear translocation (Pratt, 1993). Therefore, substances that dissociate these proteins may facilitate nuclear translocation of GR and augment GC action. Recently, a GRassociated heat shock protein, hsp 56, has been shown to be identical to an immunophilin, FK506binding protein (Tai et al, 1992; Yem et al, 1992). The association between immunophilin and GR suggests that FK506 may influence steroid receptor function. To support this, Ning et al demonstrated that FK506 potentiates GR-mediated gene expression by increasing the translocation of GR to the nucleus (Ning and Sanchez, 1993).

We tested this hypothesis by assessing the effect of FK506 on nuclear translocation of the GR using rheumatoid synovial fibroblasts. We showed that FK506 increased the translocation of GR to the nucleus in the presence of low concentrations of DEX. Furthermore, in the presence of DEX, transactivation of the glucocorticoid-responsive promoter was increased by FK506 pretreatment. These results suggest that FK506 interacts with the GR-associated hsp56 or other FK506-binding proteins and facilitates the dissociation of GR and chaperone proteins with subsequent nuclear translocation. Thus, our results identify a new model in which FK506 potentiates GRmediated transcriptional regulation by enhancing the translocation of GR in human synovial fibroblasts.

FK506-bound hsp56 does not form a complex with or inhibit the phosphatase activity of calcineurin (Lebeau et al, 1994). So it seems unlikely that calcineurin phosphatase inhibition is related the synergistic interaction between FK506 and steroid. Additionally, Hsp 90, hsp70 and GR were co-isolated with FKBP (Wiederrecht et al, 1992), and hsp 90 has the immunophilinbinding region (Peattie et al, 1992). It is possible that, in addition to hsp56, these proteins can interact with GR and are responsible for FK-506-mediated GR translocation.

COX is an important regulatory enzyme for the biosynthesis of PG (Needleman et al, 1986). COX-2, one of the two forms of COX, is highly inducible by cytokines and growth factors and is responsible for PG synthesis at inflammatory sites (Jones et al, 1993). Therefore, up-regulation of COX-2 in the synovium is regarded as the mechanism mediating the high $P G$ levels in synovial inflammation. The expression of COX-2 is regulated at a transcriptional level (Appleby et al, 1994). Furthermore, the promoter region of the human COX-2 gene contains putative transcriptional elements such as NF-IL6 and NF-kB (Crofford et al, 1997).

It is suggested that one mechanism by which GC exerts down-regulatory effects on COX-2 expression may be due to the inhibition of NF-kB. GR is retained in the cytoplasm in an inactive state by its association with the regulatory heat shock proteins (Bamberger et al, 1996). Activation of GR requires dissociation from regulatory heat shock proteins. Activated GR rapidly translocates to the nucleus and interacts with the transcription factor, functioning as a negative regulator of transcription (Caldenhoven et al, 1995). It has been demonstrated that GR and the p65 subunit of $\mathrm{NF}-\kappa \mathrm{B}$ physically interact and that this interaction involves the Rel homology domain of p65 and the DNA-binding domain of GR (McKay and Cidlowski, 1998). This evidence suggests that the phenomenon of GR translocation and the NF- $\kappa \mathrm{B}$-signaling pathway could be linked. To investigate the interplay between $\mathrm{NF}-\kappa \mathrm{B}$ and $\mathrm{GR}$ and the molecular mechanism by which FK506 suppressed the COX-2 expression in DEX-treated synovial cells, we examined the role of NF-kB. Our data clearly indicated that the specific DNA-binding activity of NF-kB was inhibited by FK506 plus DEX (1 nM) in IL-1 $\beta$-stimulated synovial cells. In contrast, DEX (1 nm) alone did not affect this activity in the same conditions. In our experiments, a high concentration of FK506 (1000 nM) alone inhibited the DNA-binding activity of NF- $\kappa \mathrm{B}$, but this inhibition was mild compared with that of FK506 (1000 nM) plus DEX (1 nm). FK506 pretreatment alone did not affect the nuclear translocation of GR. Therefore, it is possible that this effect was induced by the inhibition of calcineurin, which was shown to stimulate NF- $\kappa$ B by enhancing inactivation of $\mathrm{I} \kappa \mathrm{B}$, an inhibitor of $\mathrm{NF}-\kappa \mathrm{B}$ (Frantz et al, 1994).

We also showed that DEX inhibits the constitutive COX-2 mRNA expression in synovial cells when used at a concentration higher than $10 \mathrm{~nm}$. However, at $1 \mathrm{~nm}$ or lower concentrations, DEX did not inhibit COX-2 mRNA expression. In contrast, FK506 pretreatment down-regulated synovial COX-2 mRNA even in the presence of as little as $1 \mathrm{nM}$ DEX. Moreover, FK506 pretreatment inhibits IL- $1 \beta$-induced COX-2 protein expression in the presence of $1 \mathrm{~nm}$ of DEX as well. This concentration (1 nM) of DEX corresponds to the physiological level of plasma GC. Therefore, we speculate that FK506 alone may elicit at least partial inhibition of synovial COX-2 expression of patients with RA. Thus, FK506 may be potentially useful as a new therapeutic modality to modify GR function by inhibiting the target gene, such as COX-2, in addition to its immunosuppressive action. 
In conclusion, our results suggest that FK506 inhibits COX-2 expression in human rheumatoid synovial cells in the presence of relatively low concentrations of GCs. This inhibitory effect of FK506 is most likely mediated through enhancement of ligand-dependent GR nuclear translocation.

\section{Materials and Methods}

\section{Reagents}

FK506 was kindly provided by Fujisawa Pharmaceutical Company (Osaka, Japan). All other reagents were purchased from Sigma Chemical (St. Louis, Missouri).

\section{Synovial Cell Culture}

The experimental protocol was approved by the local ethics committee, and a signed consent form was obtained from each patient. Synovial tissue samples were obtained from patients with RA during synovectomy. The synovial membranes were minced aseptically, then dissociated enzymatically with collagenase $\left(4.0 \mathrm{mg} / \mathrm{ml}\right.$, Sigma) in RPMI 1640 for 4 hours at $37^{\circ} \mathrm{C}$. The cells were plated on culture dishes and allowed to adhere. To eliminate non-adherent cells from synovial cell preparations, the plated cells were cultured for 18 hours with RPMI 1640 supplemented with 10\% FCS at $37^{\circ} \mathrm{C}$ in humidified $5 \% \mathrm{CO}_{2}$ in air. The cells were then washed thoroughly with phosphate-buffered saline (PBS) solution. Adherent synovial cells were removed by adding trypsin-EDTA followed by washing with PBS containing $2 \%$ FCS. The collected synovial cells were used at the third or fourth passages for subsequent experiments. Synovial cell preparations were less than $1 \%$ reactive with monoclonal antibodies CD3, CD20, CD68 (Coulter Electronics, Miami Lake, Florida), and anti-human von Willebrand factor (Immunotech, Marseille, France), indicating that these preparations were almost free of mature T lymphocytes, B lymphocytes, monocytes/macrophages, and vascular endothelial cells.

\section{COX-2 Expression Analysis by Western Blot}

The expression of COX-2 was analyzed by the Western blot method as described previously by Crofford et al (Crofford et al, 1994). For this purpose, the cells were washed with cold PBS and lysed by the addition of a lysis buffer, containing $1 \%$ nonidet P-40, $50 \mathrm{~mm}$ Tris, (pH 7.5), $100 \mathrm{~mm} \mathrm{NaCl,} 5 \mathrm{~mm}$ EDTA, $10 \mu \mathrm{g} / \mathrm{ml}$ aprotinin, and $10 \mu \mathrm{g} / \mathrm{ml}$ leupeptin, for 20 minutes at $4^{\circ} \mathrm{C}$. Insoluble material was removed by centrifugation at $15,000 \times g$ for 15 minutes at $4^{\circ} \mathrm{C}$. The supernatant was saved and the protein concentration was determined using the BioRad protein assay kit (BioRad, Hercules, California). An identical amount of protein $(50 \mu \mathrm{g})$ from each lysate was subjected to $10 \%$ SDS-PAGE. The fractionated proteins were transferred to nitrocellulose membranes (Amersham Corporation, Arlington Heights, Illinois), and the membranes were blocked for 16 hours in a solution containing 5\% BSA, $10 \mathrm{~mm}$ Tri- $\mathrm{HCl}(\mathrm{pH} 8.2)$, and 140 $\mathrm{mm} \mathrm{NaCl}$. The blots were incubated with an anti-COX2-specific antibody (IBL Company, Fujioka, Japan) for 2 hours at room temperature. The membranes were further incubated with peroxidase-conjugated antirabbit IgG antibodies (Amersham) for 60 minutes and developed using an enhanced chemiluminescence (ECL) system (Amersham). The blots were analyzed by densitometer (Photometrics, Tucson, Arizona). Images from the densitometer were transferred to a personal computer and analyzed using IPLab Gel software (Signal Analytics Corporation, Vienna, Virginia). Results were calculated as relative units, and the density of the IL-I $\beta$-induced COX-2 protein band was assigned the value of $100 \%$. Data were expressed as a percentage of IL-1 $\beta$ control.

\section{RNA Preparation and RT-PCR Assay}

Total cellular RNA was extracted from synovial fibroblasts using guanidinium thiocyanate and phenol (RNAzol B, Cinna/Biotech Laboratory, Friendswood, Texas). First-strand cDNA was synthesized by reverse transcription at $42^{\circ} \mathrm{C}$ for 45 minutes in a $50-\mu$ l reaction mixture containing $1 \mu \mathrm{g}$ of total RNA and MuLV reverse transcriptase (GIBCO BRL, Gaithersburg, Maryland). After heating at $99^{\circ} \mathrm{C}$ for 5 minutes for denaturing, followed by cooling at $5^{\circ} \mathrm{C}$, the cDNA was used for amplification. For PCR reactions, $2 \mu$ of denatured cDNA was amplified in a $20-\mu$ l final volume with $1 \mathrm{U}$ Taq DNA polymerase (GIBCO BRL); $1 \mathrm{~mm}$ of both primers and Taq polymerase buffer containing $1.5 \mathrm{~mm} \mathrm{MgCl}_{2}$ with $1.5 \mathrm{~mm}$ of each dNTP. PCR was performed in a thermal cycler (Perkin-Elmer Cetus, Foster City, California), using a program of 25 cycles at $94^{\circ} \mathrm{C}$ for 1 minute, $60^{\circ} \mathrm{C}$ for 1 minute, $72^{\circ} \mathrm{C}$ for 1 minute, and followed by a 10 -minute extension at $72^{\circ} \mathrm{C}$. The amplified products were subjected to electrophoresis on $1.5 \%$ agarose gel.

The specific primers used included COX-2 (Vergne et al, 1998), 5'-TTCAAATGAGATTGTGGGAAAATTGCT-3' (forward primer) 5'-AGATCATCTCTGCCTGAGTATCTT-3' (reverse primer). The predicted size of the fragment was $301 \mathrm{bp}$.

$\beta$-actin, 5'-GACGAGGCCCAGA GCA AGAGAG-3' (forward primer), 5'-ACGTACA TGGCTGGGGTGTTG-3' (reverse primer). The predicted size of the fragment was $284 \mathrm{bp}$.

\section{Immunocytochemical Analysis of Subcellular Localization of GR}

Cells grown on eight-chambered sterile glass slides (Nippon Becton \& Dickinson, Tokyo, Japan) were fixed for immunostaining using a freshly prepared solution of $4 \%$ paraformaldehyde (wt/vol) in PBS overnight at $4^{\circ} \mathrm{C}$. Immunocytochemistry was carried out as described previously (Tanaka et al, 1996) with minor modifications. Briefly, cells were washed five times with PBS at room temperature, then incubated with anti-human GR polyclonal rabbit antibody PA1-512 (Affinity Bioreagents, Neshanic Station, New Jersey) at $2 \mu \mathrm{g} / \mathrm{ml}$ in PBS containing $0.1 \%$ Triton $\mathrm{X}-100$ for 9 
hours at $4^{\circ} \mathrm{C}$. The cells were washed five times with PBS and incubated with biotinylated anti-rabbit Ig species-specific whole antibody from donkey at a dilution of 1:200 in PBS containing $0.1 \%$ Triton X-100 for 1 hour at room temperature. Cells were then washed five times with PBS and incubated with FITCconjugated streptavidin at a dilution of 1:100 in PBS containing $0.1 \%$ Triton $\mathrm{X}-100$ for 1 hour at room temperature. In the next step, the cells were washed five times with PBS and mounted with GEL/MOUNT (Biomedia Company, Foster City, California), then examined by a confocal laser microscope (model LSM510, Carl Zeiss, Oberkochen, Germany).

\section{Reporter Gene Assay}

The GC-responsive reporter plasmid pGRE-Luc has been described previously, in which the firefly luciferase gene expression is driven under the control of a tandem repeat of GC response elements (Tanaka et al, 1995; Makino et al, 1996a: Makino et al, 1996b). The $\beta$-galactosidase gene expression plasmid $\mathrm{pCH} 110$ (Pharmacia LKB Biotechnology, Uppsala, Sweden) was used as an internal control for transfection efficiency when indicated. Synovial cells were cultured in $6-\mathrm{cm}$ plastic dishes, and $2 \mu \mathrm{g}$ of pGRE-Luc was mixed with $6 \mu$ l of TransIT-LT1 reagent and added to the culture. The total amount of the plasmid was maintained at $10 \mu \mathrm{g}$ by adding an irrelevant plasmid (pGEM3Z was used unless otherwise specified). After 6 hours of incubation, the medium was replaced with fresh RPMI1640 medium supplemented with $2 \%$ dextran-coated charcoal-stripped FCS, and the cells were further cultured in the presence or absence of various ligands for 24 hours at $37^{\circ} \mathrm{C}$. Luciferase enzyme activity was determined using a luminometer (Berthold \& Company, Bad Wildbad, Germany) as described previously (Makino et al, 1996b). After normalization of transfection efficiency by $\beta$-galactosidase expression, luciferase enzyme activity was determined. Results are shown as fold induction to basal level expression.

\section{Electrophoretic Mobility Shift Assay}

The double-stranded oligonucleotide probes were end-labeled with $\left[\alpha^{-32} \mathrm{P}\right] \mathrm{dCTP}$ (Amersham-Pharmacia) using Klenow fragments of DNA polymerase I (TaKaRa, Kyoto, Japan), and unincorporated nucleotides were chromatographically separated with a Nick column (Amersham-Pharmacia). Nuclear proteins (1-2 $\mu \mathrm{g}$ ), prepared according to Dignam (Dignam et al, 1983), were used in a $20-\mu$ l binding mixture containing 4\% glycerol, $1 \mathrm{~mm} \mathrm{MgCl} 2,0.5 \mathrm{~mm}$ EDTA, $1 \mathrm{~mm}$ dithiothreitol, $50 \mathrm{~mm} \mathrm{KCl,} 10 \mathrm{~mm}$ Tris- $\mathrm{Cl} \mathrm{pH} 7.5$ and 1 $\mu \mathrm{g}$ poly (dl-dC) according to Newton et al (Newton et al, 1996), with minor modification. After incubation on ice for 30 minutes, $0.5 \mathrm{ng}$ of ${ }^{32} \mathrm{P}$-end-labeled doublestranded oligonucleotide probe was added. The binding reactions were carried out on ice for 15 minutes. Specificity of binding was determined by the prior addition of a 20 -fold excess of unlabeled competitor consensus oligonucleotide. For supershift analysis, nuclear extracts were incubated on ice for 1 hour with antisera, raised to p50 and p65 subunits (Santa Cruz, California), at $0.5 \mu \mathrm{g} / \mathrm{ml}$, before the addition of radiolabeled oligonucleotide. Then the reaction mixture was loaded onto a $4 \%$ non-denaturing polyacrylamide gel containing $0.25 \times$ TBE $(1 \times$ TBE is composed of 89 $\mathrm{mm}$ Tris-base, $89 \mathrm{~mm}$ boric acid and $2 \mathrm{~mm}$ EDTA). The gels were run at $300 \mathrm{~V}$ for 2 hours and vacuum dried, and the results were visualized by autoradiography using Hyperfilm (Amersham-Pharmacia) and an intensifying screen. The upper strand sequence of the synthetic oligonucleotides containing a consensus NF-kB recognition site, GC response element, and hypoxia response element were: 5'-CTCGAGTTGAGGGGACTTTCCCAGGCG-3' (Lenard and Baltimore 1989); 5'-CGAGTAGCTAGAACAGACTGTTCTGAGG-3' (Makino et al, 1996b); 5'-AGTCGCCCTACGTGCTGTCTCACTGA-3' (Wang and Semenza 1995); respectively.

\section{Acknowledgement}

This work was supported by Fujisawa Pharmaceutical Company.

\section{References}

Appleby SB, Ristimaki A, Neilson K, Narko K, and Hla T (1994). Structure of the human cyclooxygenase-2 gene. Biochem J 302:723-727.

Bamberger CM, Schulte HM, and Chrousos GP (1996). Molecular determinants of glucocorticoid receptor function and tissue sensitivity to glucocorticoids. Endocr Rev 17:245261.

Caldenhoven E, Liden J, Wissink S, Van de Stolpe A, Raaijmakers J, Koenderman L, Okret S, Gustafasson J-A, and Van de Saag PT (1995). Negative cross-talk between Rel A and the glucocorticoid receptor: A possible mechanism for the anti-inflammatory action of glucocorticoid. Mol Endocrinol 9:401-412.

Crofford LJ, Wilder RL, Ristimaki AP, Sano H, Remmers EF, Epps HR, and Hla T (1994). Cyclooxygenase-1 and -2 expression in rheumatoid synovial tissues: Effects of interleukin- $1 \beta$, phorbol ester and corticosteroids. J Clin Invest 93:1095-1101.

Crofford LJ, Tan B, McCarthy CJ, and Hla T (1997). Involvement of nuclear factor $\mathrm{kB}$ in the regulation of cyclooxygenase- 2 expression by interleukin- 1 in rheumatoid synoviocytes. Arthritis Rheum 40:226-236.

Dayer J-M, de Rochemonteix B, Burrus B, Demczuk S, and Dinarello CA (1986). Human recombinant interleukin 1 stimulates collagenase and prostaglandin $\mathrm{E}_{2}$ production by human synovial cells. J Clin Invest 77:645-648.

Dignam JD, Lebovitz RM, and Roeder RG (1983). Accurate transcription initiation by RNA polymerase II in a soluble extract from isolated mammalian nuclei. Nucleic Acid Res 11:1475-1489.

Evett GE, Xie W, Chipman JG, Robertson DL, and Simmons DL (1993). Prostaglandin G/H synthase isoenzyme 2 expression in fibroblasts: Regulation by dexamethasone, mitogens and oncogenes. Arch Biochem Biophys 306:169-177. 
Frantz B, Nordby EC, Bren G, Steffan N, Paya CV, Kincaid RL, Tocci MJ, O'Keefe SJ, and O'Neill EA (1994). Calcineurin acts in synergy with PMA to inactivate I kappa B/MAD3, an inhibitor of NF-kappa B. EMBO J 13:861-870.

Jones DA, Carlton DP, Mclntyre TM, Zimmerman GA, and Prescott SM (1993). Molecular cloning of human prostaglandin endoperoxidase synthase type II and demonstration of expression in response to cytokines. J Biol Chem 268:90499054.

Lebeau MC, Myagkikh I, Rouviere-Fourmy N, Baulieu EE, and Klee CB (1994). Rabbit FKBP-59/HBI does not inhibit calcineurin activity in vitro. Biochem Biophys Res Commun 203:750-755.

Lenard MJ and Baltimore D (1989). NF-kappa B: a pleiotropic mediator of inducible and tissue-specific gene control. Cell 58:227-229.

Makino Y, Tanaka H, Dahlman-Wright $\mathrm{K}$, and Makino I (1996a) Modulation of glucocorticoid-inducible gene expression by metal ions. Mol Pharmacol 49:612-620.

Makino Y, Okamoto K, Yoshikawa N, Aoshima M, Hirota K, Yodoi J, Umesino K, Makino I, and Tanaka H (1996b) Thioredoxin: A redox-regulating cellular cofactor for glucocorticoid hormone action. J Clin Invest 98:2469-2477.

McKay LI and Cidlowski JA (1998). Cross-talk between nuclear factor $\kappa \mathrm{B}$ and the steroid hormone receptor: Mechanisms of mutual antagonism. Mol Endocrinol 12:45-56.

Needleman P, Turk J, Jakschik BA, Morrison AR, and Lefkowith JB (1986). Arachidonic acid metabolism. Ann Rev Biochem 55:69-102.

Newton R, Adcock I, and Barners PJ (1996). Superinduction of NF- $\kappa \mathrm{B}$ by actinomycin $\mathrm{D}$ and cycloheximide in epithelial cells. Biochem Biophys Res Commun 218:518-523.

Ning Y-M and Sanchez ER (1993). Potentiation of glucocorticoid receptor-mediated gene expression by the immunophilin ligand FK506 and rapamycin. J Biol Chem 268: 6073-6076.

Peattie DA, Harding MW, Fleming MA, DeCenzo MT, Lippke JA, Livingston DL, and Benasutti M (1992). Expression and characterization of human FKBP52, an immunophilin that associates with the $90-\mathrm{kDa}$ heat shock protein and is a component of steroid receptor complexes. Proc Natl Acad Sci USA 89:10974-10978.

Pratt WB (1993). The role of heat shock proteins in regulation the function and trafficking of glucocorticoid receptor. J Biol Chem 268:21455-21458.

Salmon JA, Higgs GA, Vane JR, Bitensky L, Chayen J, Henderson B, and Cashman B (1983). Synthesis of arachidonate cyclo-oxygenase products by human rheumatoid and non-rheumatoid synovial lining in non-proliferative organ culture. Ann Rheum Dis 42:36-39.
Smith DE and Toft DO (1993). Steroid receptors and their associated proteins. Mol Endocrinol 7:4-11.

Tai PK, Albers MW, Chang H, Faber LE, and Schreiber SL (1992). Association of a 59-kilodalton immunophilin with the glucocorticoid receptor complex. Science 256:1315-1318.

Tanaka H, Makino Y, Wright K-D, Gustafsson J-A, Okamoto K, and Makino I (1995). Zinc ions antagonize the inhibitory effect of authiomalate on glucocorticoid receptor function at physiological concentrations. Mol Pharmacol 48:938-945.

Tanaka H, Makino Y, Miura T, Hirano F, Okamoto K, Komura K, Sato Y, and Makino I (1996). Ligand-independent activation of the glucocorticoid receptor by ursodeoxycholic acid. J. Immunol 156:1601-1608.

Truss M and Beato M (1993). Steroid hormone receptors: interaction with deoxyribonucleic acid and transcription factors. Endocr Rev 14:459-479.

Vergne P, Liagre B, Bertin P, Cook-Moreau J, Treves R, Beneytout J-L, and Rigaud M (1998). Methotrexate and cyclooxygenase metabolism in cultured rheumatoid synoviocytes. J Rheumatol 25:433-440.

Wang GL and Semenza GL (1995). Purification and characterization of hypoxia-inducible factor-1. J Biol Chem 270: 1230-1237.

Wiederrecht G, Hung S, Chan HK, Marcy A, Martin M, Calaycay I, Boulton D, Sigal N, Kincaid RL, and Siekierka JJ (1992). Characterization of high molecular weight FK506 binding activities reveals a novel FK-506-binding protein as well as a protein complex. J Biol Chem 267:21753-21760.

Wittenberg RH, Willburger RE, Kleemeyer KS, and Peskar BA (1993). In vitro release of prostaglandins and leukotrienes from synovial tissue, cartilage, and bone in degenerative joint disease. Arthritis Rheum 36:1444-50.

Yem AW, Tomasselli AG, Heinrikson RL, Zurcher-Neely $H$, Ruff VA, Johnson RA, and Deibel MR (1992). The hsp56 component of steroid receptor complexes binds to the immobilized FK506 and shows homology to FKBP-12 and FKBP-13. J Biol Chem 267:2868-2871.

Zvaifler NJ and Firestein GC (1994). Pannus and pannocytes. Alternative models of destruction in rheumatoid arthritis. Arthritis Rheum 37:783-789. 